\title{
A HYDROPHYSICAL ANALYSIS OF URBAN SURFACE RUNOFF, CHANNEL CHARACTERISTICS, AND THE INCIDENCE OF FLOOD AND EROSION OVER THE CALABAR DRAINAGE AREA, NIGERIA
}

\author{
Innocent Akwazi Ugbong ${ }^{1}$, Ivan Vladimirovich Budagov ${ }^{1}$ \\ 1 Kuban State Technological University, Moskovskaya 2, 350072 Krasnodar, Russia, e-mail: inno_ugbong@ \\ yahoo.com, ivan_budagov@mail.ru
}

Received: 2016.03.04 Accepted: 2016.06.01 Published: 2016.07.01

\begin{abstract}
Hydro-physical processes operating in the Calabar drainage area were analyzed by estimating the volume of surface runoff carried in each basin and sub-basin, using field measurements of flow velocities in conjunction with the "Rational Method" mathematical model proposed by civil and environmental engineers. It was found that run-off flow is affected by at least three factors which either produce floods or erosion conditions. The factors include size of catchment areas, gradient and lengths of flow channels. The Multiple Regression statistic was used to test these relationships. The results showed a strong statistical correlation among these variables, as well as between these variables and flow characteristics. It was found that for all the basins, runoff volume increased with increasing surface area of the catchment; just as areas with lower elevations register higher flow volume accompanied by flooding; with a reversed condition in higher ground where higher velocities are found with resultant erosion conditions. Also channels with considerable lengths receive higher flows along their courses downstream, and thus produce floods. It was therefore, recommended that in addition to the six major drainage channels recommended for the area, each channel and each segment of a channel should be determined by its gradient, drainage area, length of flow channel.
\end{abstract}

Keywords: drainage, channels, runoff volume, flood and erosion, gradient, drainage area, channel length

\section{INTRODUCTION}

Several theoretical and practical works have been done on run-off-induced natural disasters. These include researches on floods (using the Time Series approach), erosion rates (based on changes in gully-depth), as well as on volume of sediment yield. There is a general consensus that human activities help to accelerate these hazards. For example Adefolalu (2008) attributes flooding to the building up of flood plains and construction of structures across slopes. In all these studies, adequate channelization and planting of vegetation have been suggested as remedies. At the engineering level, it has been suggested that design of storm drains should be based on flood frequency for the affected area, while trapezoidal and closed up drains are recommended in accordance with flood magnitude. All these have in many instances produced very short-term and highly localized results, helping only to alter the points of incidence of either flood or erosion, because the approaches hardly take into account the over-all runoff characteristics of the given region (Parker, 2015). This paper attempts a determination of the total Volume of Surface Run-off Discharge per unit of sub-basin within the Calabar drainage area, as well as determination of the controlling factors. This is with a view to providing a new insight into the intractable problem of flooding and erosion in the region. 
One of the unique characteristics of urban flooding problem facing the Calabar region is that floods are not caused by the overflow of the two rivers that sandwich the city or by tidal waves as a coastal city. Rather floods are caused by storm runoff which is generated after every heavy rainstorm. A study of the topography of Calabar has shown that the city has a total of six major drainage basins; with seventy-three sub-basins (Ugbong and Budagov, 2016). In effect, runoff discharge defines the mean velocity of surface water passing through a given cross-sectional area in a given unit of time (Guinness and Nagel, 2006). This is very important in the determination of flood peaks since floods occur when the volume of flow can no longer be contained within the margins of its normal channel. Runoff itself is a product of rainfall whose intensity exceeds the infiltration capacity of the soil (Itam et al, 2015a). According to Adefolalu (2008), at the time of floods, the rate of rainfall is much higher than the infiltration capacity of the soil. Total amount over a short du- ration of the thunderstorm is often very high with the result that the intensity of fall per hour is high.

\section{THE STUDY AREA}

Calabar is located in the subequatorial climatic zone of south eastern Nigeria: at latitude 04.58 degrees north of the Equator and longitude 08.21 degrees east of the Greenwich Meridian (see Fig. 2). The annual average rainfall is about $3030.2 \mathrm{~mm}$. The heaviest rainfalls occur in the months spanning from June to September; and the average rainfall for these four months is slightly above 4000 millimetres. The maximum rainfall is recorded in June: about 4040 millimetres on the average (see Figures 1). The driest period of the year is December - January. There are usually less than five rain days per month in the dry season, but as many as 25-27 days in the wettest part of the year. (A rainy day is said to occur if rainfall is greater than $1 \mathrm{~mm}$. Thus, on the average in

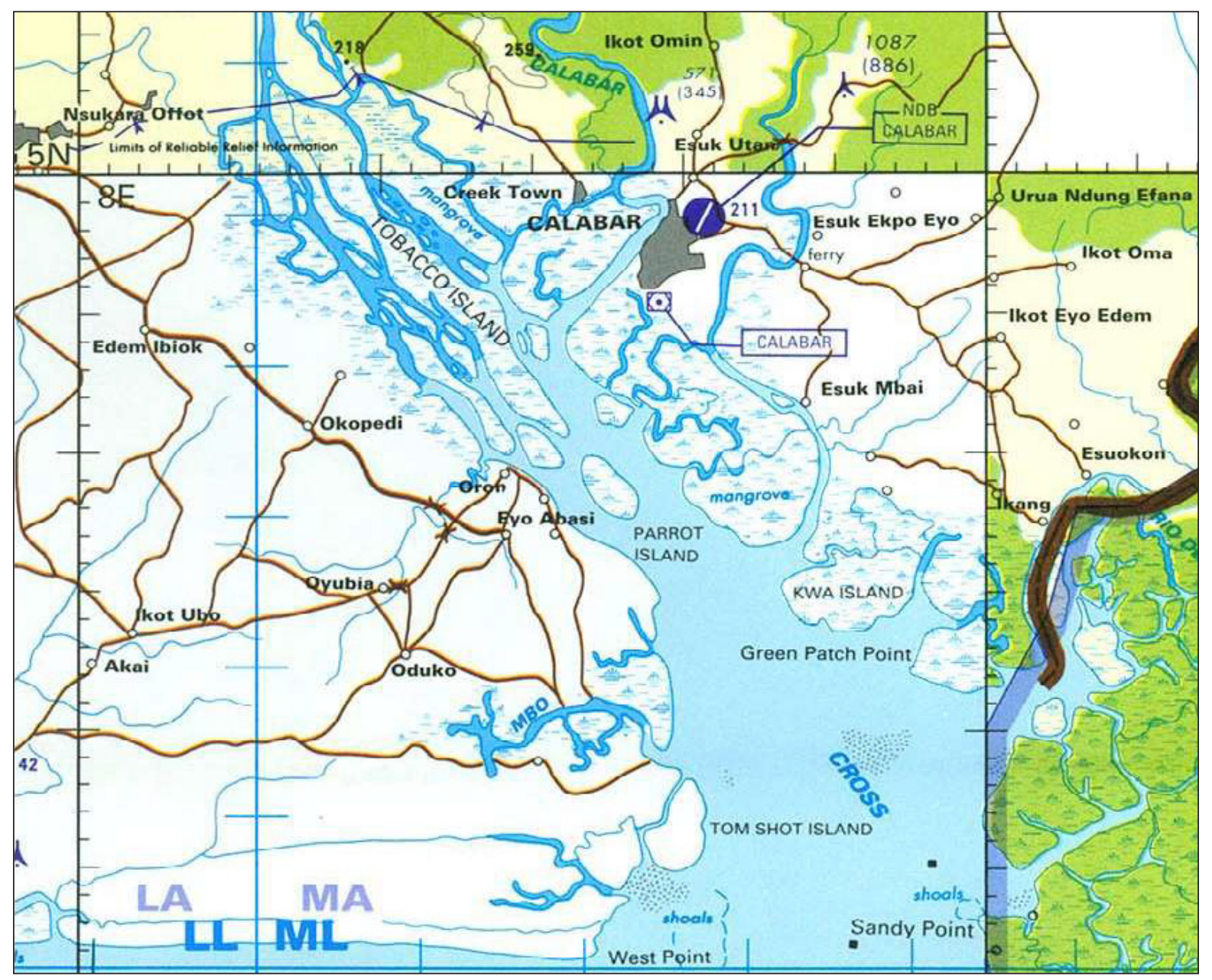

Figure 1. Calabar, capital city of Cross River State, Nigeria (as compiled in April 1995) [http://www.lib.utexas. edu/maps/africa/calabar_tpc_1996.jpg Retrieved: January 14, 2016] 
Calabar, the amount of rainwater that would pour over 1 hectare of land throughout the 4 months spanning from June to September, would be in the order of 4,400 cubic metres $(100 \times 100 \times 0.41$ $\left.=4.1 \times 103 \mathrm{~m}^{3}\right)$. This quantity of water has great potential in providing vast ecological and agricultural benefits to the city if properly harnessed; but it also has the potential for inflicting grave ecological damage if mismanaged (Itam et al, 2015b).

Because of their important role in the formation of storm drainage peaks, the characteristics of the high-intensity, short-duration rainfall was carefully analyzed. The intensity-duration curves based on records of the 1986-1994 periods were drawn up for different return periods.

The drainage system of Calabar is hinged around two rivers, the Great Kwa and Calabar Rivers. However, there are no flow data available for either river. However considering the rainfall regime and the characteristics of the drainage network, it was possible to assume that low flows occur in January - February, and flood flows in August - September. Also the water-courses feel the influence of ocean tides from the Atlantic Ocean, which run up the rivers for some ten or twelve kilometers from their mouths. Observations show that influences are felt from the late afternoon hours.

\section{MATERIALS AND METHODS}

\section{Empirical Analysis}

The basic data used to calculate flows in the drainage system were: rainfall intensity-duration curves and land use characteristics as envisaged in the Calabar master plan, as well as morphological information (areas, lengths and slopes) derived from the 1:12000 map (Figure 2). In estimating the flows a total seventy-three (73) locations, spread across the seventy-three sub-basins delineated above were designated. First the character of rain fall which influences run-off in the area was analyzed along with the tidal oscillations of the two major rivers which eventually collect the run-off. Thereafter, the study examines the nature of controlling factors over flow response, which in turn determine the points of incidence of flood and erosion in the study area.

Furthermore, the Rational Method was used to compute run-off discharge for each basin. The method takes account of the factors which con-

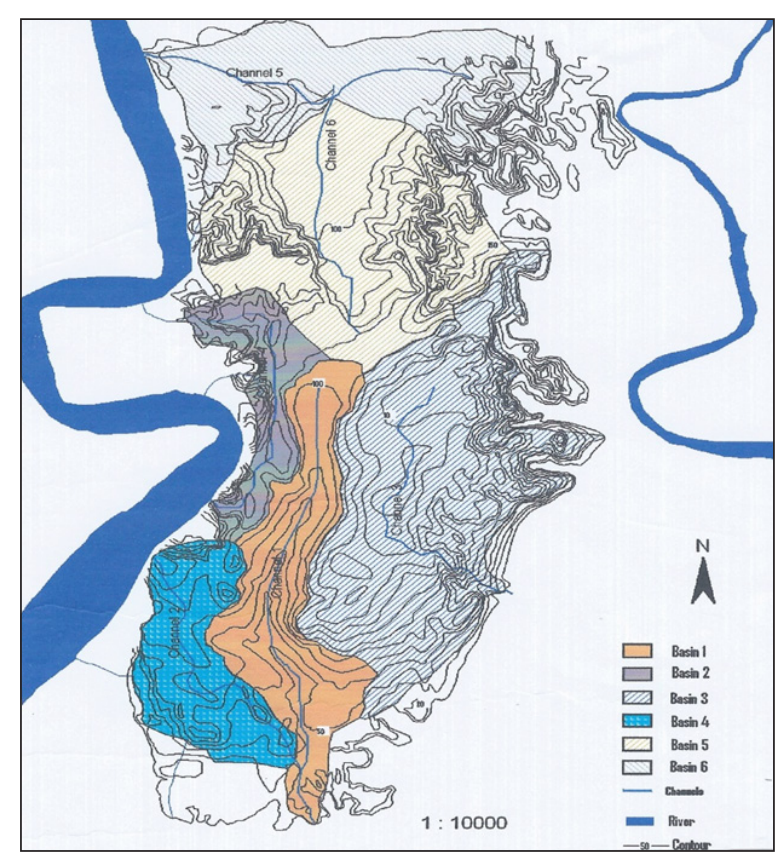

Figure 2. Detailed contour layout of Calabar showing designated drainage basins and channels derived from contour crenulations [Ugbong and Budagov, 2016]

trol the amount of water conveyed to a drainage system during rainstorm. This include rate of rainfall, character of the ground surface, size and slope characteristics of the drainage system. It was necessary therefore to first summarize the rainfall characteristics of the study area and then move on to show the volume of discharge per sub-basin. The expected controlling factors on discharge, vis: Gradient, size of drainage area and length of flow Channels, are thereafter tested by correlation and regression.

Values of maximum discharge $\left(Q_{\max }\right)$ for each unit area were computed using the Rational Method formula give as:

$$
\mathrm{Q}_{\max }=\Psi \frac{1 \times \mathrm{A}}{360}=0.0028=\Psi \mathrm{l} . \mathrm{A}
$$

Once again the terms $\Psi$ and $I$ defined run-off co-efficient and rainfall intensity respectively. Rainfall intensity is expressed in $\mathrm{mm} / \mathrm{h}$, for duration equal to the concentration time of the basin involved. In this case was computed in terms of concentration time $(t c)$. According to Niger-Technical (2011), the assumption that tc is representative of the response time of the basin concerned is satisfactory for small basins general, and the other basic assumptions inherent in the formula may also be considered acceptable for basins with paved areas. It was also instructive to remember that the determination of run-off co-efficient in 
the rational formula depends on the characteristics of the drainage basin, i.e. on the type of land use, type of pavement, slope of the area and so on.

Based on these conditions and parameters, it was possible to compute the maximum discharge values for the seventy - three locations. Tables (i-iv) show the flow discharge values that were obtained. Each table shows values for each basin, along with gradients, drainage areas, and distances between points of flow calculation.

\section{Flow Discharge Estimates}

Tables 1 to 4 represent the four of the six basins delineated as shown on the map. Note also that the run-off, discharge values are arranged in a downstream direction, from top to bottom. A column showing cumulative flows is also included to show the down-stream change in the magnitude of flow. It was expected that the cumulative flow calculations will vary very little from the partial flow calculations for each sub-basin downstream. But this was not the case. As can be seen from the tables the degree of variance was obviously so strong that some controlling factors had to be examine.

Since there is fairly uniform rainfall intensity and infiltration rates over each unit sub-basin, it was predicted that variation in flow could be affected by the size of drainage areas contributing run-off to each channel, as well as slope gradient and the average lengths of flow channels. Slope gradient and lengths of channel were pre-determined from Figure 3. Gradient was calculated in terms of contour heights over a measuring location. Values for these parameters were computed for individual sub-basins as shown in the tables along with the flow calculations.

\section{Statistical Analysis}

While the fore-going empirical analysis was used in generating a mass of the data set, statistical analysis is here applied in order to test the relationship among the identified variables. According to Granger et al (2010), statistical techniques are being increasingly used in the morphological analysis of landscape. It has also been accepted by Chorley and Kennedy (2001) that if a large number of morphological variables for example statistically correlate significantly, then this may indicate conditions of physical equilibrium. By way of example, Chorley and Kennedy showed evidence that where there is removal by streams from the base of slopes, a high degree of significant correlation may be found of a number of variables.

Table 1. Values of sub-basin areas, gradient, linear distance from basin head through flow points and $\mathrm{r}_{0}$ flow calculations (basin 1)

\begin{tabular}{|c|c|c|c|c|c|c|}
\hline No. & $\begin{array}{c}\text { Section of } \\
\text { reference } \\
\text { (sub-basin 1) }\end{array}$ & $\begin{array}{l}\text { Sub-basin area } \\
\text { (in ha) }\end{array}$ & \begin{tabular}{|c|}
$\begin{array}{c}\text { Gradient at point } \\
\text { of flow calculation } \\
\text { (in metres) }\end{array}$ \\
\end{tabular} & $\begin{array}{c}\text { Cummulative linear } \\
\text { dist. B/w flow } \\
\text { calculation (in } \mathrm{km} \text { ) }\end{array}$ & $\begin{array}{l}\text { Run-off partial flow } \\
\text { calculations }\left(\mathrm{m}^{3} / \mathrm{sec}\right)\end{array}$ & $\begin{array}{c}\text { Run-off cummulative } \\
\text { flow calculations } \\
\text { (in } \mathrm{m}^{3} / \mathrm{sec} \text { ) }\end{array}$ \\
\hline 1 & 1.A & 20.50 & 115 & 0.000 & 4.62 & 4.62 \\
\hline 2 & 1.B & 9.37 & 105 & 0.192 & 1.53 & 6.45 \\
\hline 3 & 1.C & 9.37 & 98 & 0.389 & 1.53 & 7.98 \\
\hline 4 & 1.D & 11.63 & 96 & 0.590 & 2.48 & 10.46 \\
\hline 5 & 1.E & 11.63 & 95 & 0.758 & 2.48 & 12.96 \\
\hline 6 & $1 . \mathrm{F}$ & 13.12 & 90 & 1.046 & 2.92 & 15.86 \\
\hline 7 & $1 . G$ & 12.87 & 85 & 1.286 & 3.01 & 18.87 \\
\hline 8 & $1 . \mathrm{H}$ & 19.84 & 78 & 1.526 & 4.63 & 23.50 \\
\hline 9 & 1.L & 34.33 & 75 & 1.766 & 8.01 & 36.89 \\
\hline 10 & 1.M & 24.30 & 72 & 1.934 & 5.67 & 42.56 \\
\hline 11 & $1 . \mathrm{N}$ & 29.36 & 70 & 2.275 & 6.85 & 49.41 \\
\hline 12 & 1.0 & 1.11 & 71 & 2.731 & 0.26 & 83.11 \\
\hline 13 & 1.P & 12.00 & 60 & 2.947 & 2.80 & 85.91 \\
\hline 14 & $1 . Q$ & 23.10 & 55 & 3.274 & 5.39 & 91.30 \\
\hline 15 & $1 . R$ & 23.14 & 47 & 3.706 & 5.40 & 96.70 \\
\hline 16 & $1 . S$ & 33.99 & 44 & 4.042 & 7.93 & 162.91 \\
\hline 17 & 1.T & 32.20 & 35 & 4.690 & 8.05 & 170.76 \\
\hline 18 & 1.V & 35.08 & 42 & 4.891 & 7.60 & 178.56 \\
\hline
\end{tabular}

Source: Author's field survey and laboratory analysis, with additional information from TESCO-KOTZ and Niger-Techno (2011) 
Table 2. Values of sub-basin areas, gradient, linear distance from basin head through flow points and $\mathrm{r}_{0}$ flow calculations (basin 2)

\begin{tabular}{|c|c|c|c|c|c|c|}
\hline No. & $\begin{array}{c}\text { Section of reference } \\
\text { for flow calculation } \\
\text { (sub-basin 2) }\end{array}$ & $\begin{array}{c}\text { Sub-basin } \\
\text { area (in ha) }\end{array}$ & $\begin{array}{c}\text { Gradient at point } \\
\text { of flow calculation } \\
\text { (in metres) }\end{array}$ & $\begin{array}{c}\text { Cummulative linear } \\
\text { dist. B/w flow } \\
\text { calculation (in km) }\end{array}$ & $\begin{array}{c}\text { Run-off partial flow } \\
\text { calculations (m³/sec) }\end{array}$ & $\begin{array}{c}\text { Run-off cummulative } \\
\text { flow calculations } \\
\left.\text { (in } \mathrm{m}^{3} / \mathrm{sec}\right)\end{array}$ \\
\hline 1 & $2 . \mathrm{A}$ & 48.55 & 127 & 0.000 & 11.06 & 11.06 \\
\hline 2 & $2 . \mathrm{B}$ & 14.72 & 118 & 0.168 & 3.43 & 14.49 \\
\hline 3 & $2 . \mathrm{C}$ & 25.81 & 129 & 0.480 & 5.64 & 20.14 \\
\hline 4 & $2 . \mathrm{D}$ & 116.51 & 126 & 0.816 & 23.58 & 43.73 \\
\hline 5 & $2 . \mathrm{E}$ & 21.07 & 121 & 1.656 & 4.25 & 47.97 \\
\hline 6 & $2 . \mathrm{F}$ & 7.02 & 121 & 1.752 & 1.62 & 49.60 \\
\hline 7 & $2 . \mathrm{G}$ & 1.62 & 119 & 2.208 & 0.38 & 49.60 \\
\hline 8 & $2 . \mathrm{H}$ & 7.34 & 120.5 & 2.496 & 1.45 & 51.42 \\
\hline 9 & 2.1 & 5.57 & 116 & 2.640 & 1.36 & 52.78 \\
\hline 10 & $2 . \mathrm{L}$ & 39.79 & 113 & 2.760 & 11.10 & 63.87 \\
\hline 11 & $2 . \mathrm{M}$ & 24.41 & 115 & 3.120 & 6.87 & 70.84 \\
\hline 12 & $2 . \mathrm{N}$ & 8.93 & 112 & 3.648 & 1.90 & 72.64 \\
\hline 13 & $2 . \mathrm{O}$ & 11.21 & 113 & 3.720 & 2.62 & 75.34 \\
\hline 14 & $2 . \mathrm{P}$ & 17.89 & 10 & 4.416 & 5.37 & 80.62 \\
\hline 15 & $2 . \mathrm{Q}$ & 29.09 & 10 & 4.704 & 8.73 & 89.35 \\
\hline 16 & $2 . \mathrm{R}$ & 48.55 & 05 & 4.848 & 11.94 & 101.29 \\
\hline 17 & $2 . \mathrm{S}$ & 15.02 & 05 & 4.848 & 3.96 & 105.26 \\
\hline
\end{tabular}

Source: Author's field survey and laboratory analysis, with additional information from TESCO-KOTZ and Niger-Techno (2011)

Table 3. Values of sub-basin areas, gradient, linear distance from basin head through flow points and $\mathrm{r}_{0}$ flow calculations (basin 3)

\begin{tabular}{|c|c|c|c|c|c|c|}
\hline No. & $\begin{array}{c}\text { Section of reference } \\
\text { for flow calculation } \\
\text { (sub-basin3) }\end{array}$ & $\begin{array}{c}\text { Sub-basin } \\
\text { area (in ha) }\end{array}$ & $\begin{array}{c}\text { Gradient at point } \\
\text { of flow calculation } \\
\text { (in metres) }\end{array}$ & $\begin{array}{c}\text { Cummulative linear } \\
\text { dist. B/w flow } \\
\text { calculation (in km) }\end{array}$ & $\begin{array}{c}\text { Run-off partial flow } \\
\text { calculations (m } 3 / s e c)\end{array}$ & $\begin{array}{c}\text { Run-off cummulative } \\
\text { flow calculations } \\
\text { (in m3/sec) }\end{array}$ \\
\hline 1 & 3.A & 71.42 & 133 & 0.000 & 3.05 & 14.76 \\
\hline 2 & 3.B & 11.73 & 135 & 0.446 & 9.69 & 167.81 \\
\hline 3 & 3.C & 38.28 & 131 & 0.758 & 5.97 & 27.50 \\
\hline 4 & 3.D & 34.36 & 134 & 1.238 & 6.85 & 33.47 \\
\hline 5 & 3.E & 40.99 & 131 & 1.598 & 3.04 & 40.32 \\
\hline 6 & 3.F & 13.03 & 127 & 1.910 & 3.13 & 43.36 \\
\hline 7 & 3.G & 10.44 & 125 & 2.462 & 3.70 & 46.49 \\
\hline 8 & 3.H & 15.84 & 121 & 2.462 & 1.31 & 50.19 \\
\hline 9 & 3.I & 6.07 & 110 & 2.702 & 2.89 & 51.50 \\
\hline 10 & 3.L & 12.38 & 118 & 2.966 & 0.85 & 54.39 \\
\hline 11 & 3.M & 3.66 & 120 & 3.422 & 1.32 & 55.24 \\
\hline 12 & 3.N & 5.66 & 70 & 3.806 & 1.25 & 56.56 \\
\hline 13 & 3.O & 5.37 & 71 & 4.286 & 0.47 & 57.81 \\
\hline 14 & 3.P & 2.02 & 50 & 4.598 & & 58.28 \\
\hline
\end{tabular}

Source: Author's field survey and laboratory analysis, with additional information from TESCO-KOTZ and Niger-Techno (2011)

With the flow calculations, and the computation of drainage areas, gradients and linear distance (lengths) between flow points for each subbasin, hypothesis II was tested using the Multiple Regression statistic for four (4) of the six basins (see Table 5). For each basin, both linear and nonlinear operations were performed on the data set in to order to ensure that a better result obtained from either of the two operations is the one used for further analysis. The Non-linear operation was performed by transforming all values into a logarithmic mode. However, it was operationally impossible to model basins 4 and 5 on the same programme because of the smallness of sample sizes for the two basins. They were thus left out of the analysis. 
Table 4. Values of sub-basin areas, gradient, linear distance from basin head through flow points and $\mathrm{r}_{0}$ flow calculations (basin 4)

\begin{tabular}{|c|c|c|c|c|c|c|}
\hline No. & $\begin{array}{c}\text { Section of } \\
\text { reference (sub- } \\
\text { basin 4) }\end{array}$ & $\begin{array}{c}\text { Sub-basin } \\
\text { area (in ha) }\end{array}$ & $\begin{array}{c}\text { Gradient at point of } \\
\text { flow calculation (in } \\
\text { metres) }\end{array}$ & $\begin{array}{c}\text { Cummulative linear } \\
\text { dist. B/w flow } \\
\text { calculation (in km) }\end{array}$ & $\begin{array}{c}\text { Run-off partial flow } \\
\text { calculations (m }{ }^{3} / \mathrm{sec} \text { ) }\end{array}$ & $\begin{array}{c}\text { Run-off cummulative } \\
\text { flow calculations (in } \\
\left.\mathrm{m}^{3} / \mathrm{sec}\right)\end{array}$ \\
\hline 1 & $4 . \mathrm{A}$ & 16.60 & 112 & 0.000 & 3.87 & 3.87 \\
\hline 2 & $4 . \mathrm{B}$ & 8.31 & 103 & 0.120 & 2.08 & 5.95 \\
\hline 3 & $4 . \mathrm{C}$ & 17.57 & 105 & 0.264 & 4.29 & 10.24 \\
\hline 4 & $4 . \mathrm{D}$ & 10.70 & 100 & 0.537 & 2.50 & 12.74 \\
\hline 5 & $4 . \mathrm{E}$ & 12.40 & 93 & 0.753 & 2.90 & 15.64 \\
\hline 6 & $4 . \mathrm{F}$ & 44.49 & 78 & 1.041 & 11.15 & 26.79 \\
\hline 7 & $4 . \mathrm{G}$ & 11.59 & 72 & 1.305 & 2.70 & 29.49 \\
\hline 8 & $4 . \mathrm{H}$ & 13.54 & 66 & 1.545 & 13.16 & 32.65 \\
\hline 9 & 4.1 & 3.39 & 60 & 1.737 & 0.79 & 33.44 \\
\hline
\end{tabular}

Source: Author's field survey and laboratory analysis, with additional information from TESCO-KOTZ and Niger-Techno (2011)

The multiple regression equation is given by the formula.

$$
Y=a+b_{1} X_{1}+b_{2} x_{2}+\ldots b_{n} x_{n}+e
$$

where: $Y$-dependent variable

$a-\mathrm{Y}$ intersect,

$b$ - gradient,

$X$ - the independent variable.

According to Parker (2015), Multiple Regression is necessary to estimate the parameters $\mathrm{b}_{1}, \mathrm{~b}_{2}, \mathrm{~b}_{3} \ldots \mathrm{b}_{\mathrm{n}}$, which are called impact multipliers. They tell us the magnitude of the defect of a unit change in the independent variables on the dependent variable. The explicability of the Multiple Regression model is determined by the $\mathrm{R}^{2}$ called the coefficient of Multiple Determination given by Parker (2015).

The F-ratio was used in the regression analysis to indicate the statistical significance of the test. This calculated F-value was compared with the table of values at 0.05 or 95 percent level of significance to confirm the hypothesis for each basin. The T-statistic was also calculated in the model to establish a statistical difference between each of the independent variables and the dependent variable. According to Freud and Walpole (1997),

$$
T=\frac{x-u}{S \sqrt{n}}
$$

where: $x$-sample mean,

$n$ - sample size

$S$ - sample standard deviation,

$U$-population mean.

\section{INTERPRETATION OF RESULTS AND DISCUSSION OF FINDINGS}

On the whole results of the fore-going analysis shows that there is a positive relationship between run-of flow (Y) and drainage area I (Xi) for all the four basins analyzed; but a negative relationship is recorded between run-off and Gradient $\left(\mathrm{X}_{2}\right)$ in basin I, 2 and 6, and also between runoff and linear distance from basin head to outlet $\left(\mathrm{X}_{3}\right)$ for basin 1, 3 and 6 . These relationships are shown in Table 5.

The expressed relationship between run-off flow (y) and drainage area $\left(\mathrm{x}_{1}\right)$ is in consonance with theoretical expectation since according to Strahler and Strahler (1979) average discharge of a stream or overland flow increases with increase drainage basin area. It remains to be determined what mathematical model.

A study of Potomac River basin, U.S.A. by J.T. Hack (1957) (as cited in Strahler and Strahler, 1979), shows that when flow discharge was plotted against basin area, the fitted straight line ran at $45^{\circ}$ across the graph. It shows that flow discharge increase in direct Proportion to the basin area.

One practical use of such established mathematical relationship between discharge and basin area is that it enables the hydrologist to estimate

Table 5. +ve and -ve signs of Coefficient of variables for the four basins.

\begin{tabular}{|l|c|c|c|c|}
\hline \multicolumn{1}{|c|}{ Variables } & B1 & B2 & B3 & B6 \\
\hline Qmax FloQw $(\mathrm{Y})$ & $+\mathrm{ve}$ & $-\mathrm{ve}$ & $-\mathrm{ve}$ & $-\mathrm{ve}$ \\
\hline Area $\left(\mathrm{x}_{1}\right) \mathrm{Ua}$ & $+\mathrm{ve}$ & $+\mathrm{ve}$ & $+\mathrm{ve}$ & $+\mathrm{ve}$ \\
\hline Gradient $\left(\mathrm{x}_{2}\right) /\left.\right|^{\left(\mathrm{X}_{2}\right)}$ & $-\mathrm{ve}$ & $-\mathrm{ve}$ & $+\mathrm{ve}$ & $-\mathrm{ve}$ \\
\hline Distance $\left(\mathrm{x}_{3}\right)$ & $-\mathrm{ve}$ & $+\mathrm{ve}$ & $-\mathrm{ve}$ & - \\
\hline
\end{tabular}


Basin 1
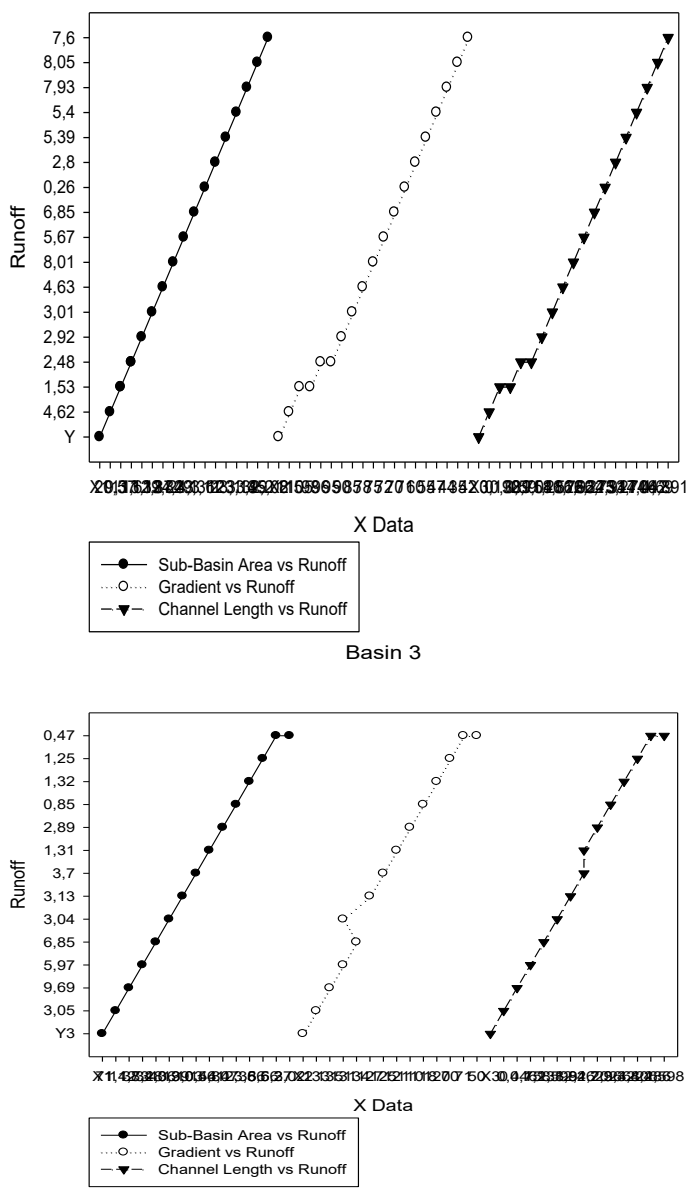

Basin 2
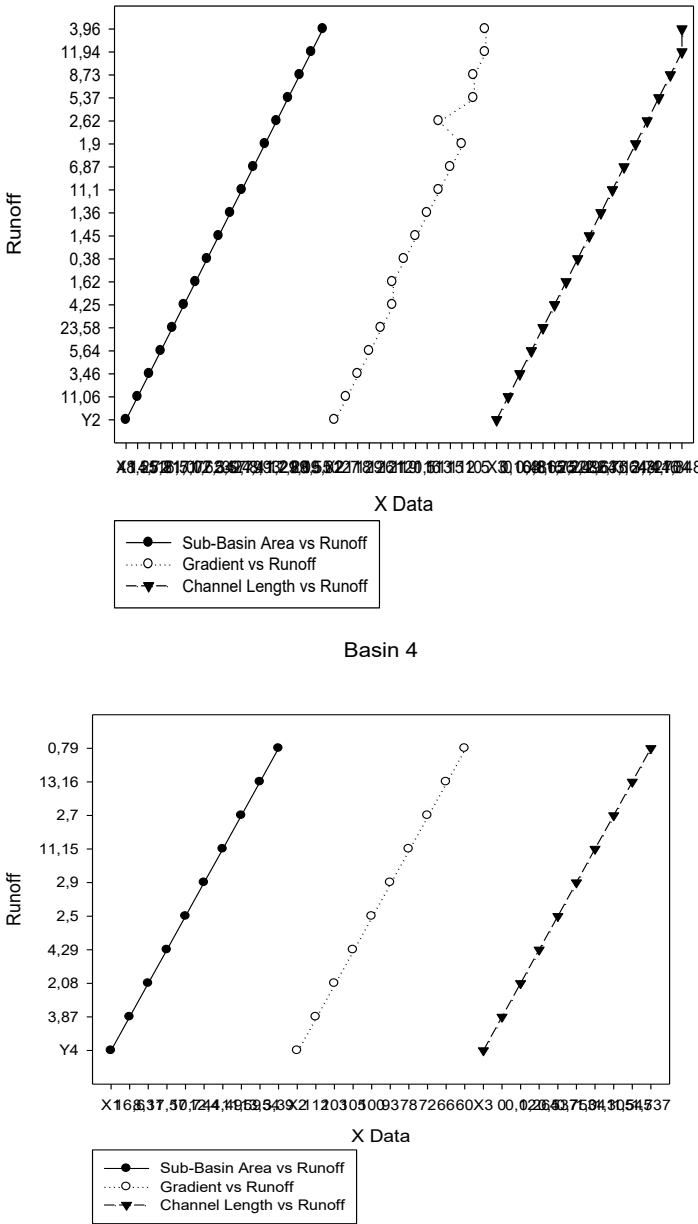

Figure 3. Regression graphs showing the relationship between Runoff Discharge on the one hand; and Gradient, sub-basin Area, and the linear distance between flow points, on the other

mean discharge at any point in the flow system by measuring the watershed area lying above that point (Zieder et al, 2006). Such knowledge would also be essential in designing hydraulic structures such as storm drains, bridges, irrigation diversions and dams. Moreover, if man-made changes in a particular area should alter the soil-water budget, the effect may be recognized by a marked departure of data of a given gauge point from the normal trend. It is not surprising therefore, that basin 1 records the highest cumulative flow, since its area surface is almost the size of other five basins put together.

Similarly, the negative relationships between flow discharge and gradient $\left(\mathrm{X}_{2}\right)$ in basins 1,2 and 6 is in conformity with expected results. It is intuitively obvious that water will flow faster in a channel of steep gradient than in one of low gradient, since according to Strahler and Strahler (1979), the components of gravity acting parallel with the bed is larger for the steeper grade. The negative sign in the coefficients indicates that flow in a lesser depth or higher ground will be less than on a steeper or lower ground. The reason as noted by Zhou (2014) is because the motion between successive water layers is accumulated upward from the bed and outward from the banks. The Chenzy equation confirms this when it states in words that "mean velocity varies directly as the square-root of the slope..."

On the other hand, negative signs which relate the coefficients of linear distance and run-off flow is not in consonance with theoretical expectation since according to Daniel (2001), the dendritic Pattern of channels represents the effective compromise between length of flow path and run-off discharge, while at the same time carrying water supplied by the basin surface.

In other words it is expected that discharge increases with increasing distance downstream. But the negative sign shows an inverse relationship. However, from field observation this sign 
shows that discharge increases even with the smallest change in distance downstream. That is to say flow discharge increases more rapidly than the change in distance downstream. It was also observed that there were reduced downstream velocities in a few channels arising from widened channels and the age of the channels in those segments. In sum, there must be a built-in geometrical compromise between two aspects of the drainage system efficiency (Chocat, 2007).

On the one hand, the shortest distance between a point on the divide and the exit point will have the steepest average gradient and will minimize flow resistance for a single channel. On the other hand, one large flow channel is more efficient in discharging run-off than several small channels carrying the same flow. In other words, when this relationship is examined in terms of all other factors affecting runoff, we find that there is an explainable interconnection: as channels of a network increase in length and size, and hence in water discharge, they also decrease in gradient.

\section{Flow Characteristics and the Incidence of Flood and Erosion}

By definition, a condition of flood exists when runoff discharge cannot be accommodated within the margins of normal channels, so that water spreads over adjoining ground. Erosion on the other hand is the removal and transportation of soil particles, running water or wind (Parkinson, 2010). The fore-going runoff calculations and factors affecting them thus, have their definite expression in flooding and erosion in the landscape.

The down-stream segment of all basins in the study area recorded high flow, lower gradients and increased distances from the basin heads. This lower segment marked the location of all high or flash flood points. Other locations of flood points within the basins are determined by other factors. These include locations where channels intersect each other discordantly against the natural flow direction, as well as at road intersections coming from heavily paved surfaces. These areas increase greatly the amount of flow generated and also the velocity of flow due to straightening of channels and removal of the infiltration components of runoff. Generally, over the entire study area, where the ground elevation ranges between $5 \mathrm{~m}$ to $35 \mathrm{~m}$ above sea level or slope angle ranges between $0^{\circ}$ and $2^{\circ}$, severe flooding is experienced as a result of reduced velocity of flow. Example is represented by portions of the central trough which passes through basin 1 . Also facets of land where slope angle is about $2^{\circ}$ in all directions, as for example Goldie-by-Target junction, the flat floor valley suffers severe flooding during or after a heavy storm, in spite of the super-channel passing through the area.

From the Watt Market area down the gaps in the cliff to the Calabar Coastal plain - the Marina Beach area - the run-off flow is swift because of steep slope with an angle of about $40^{\circ}$. Here the abrupt change in gradient produced very severe erosion, threatening most of the commercial houses in the area. At other locations some very low-lying areas experience such extensive flooding that they have developed into temporary swamp plates. At the outlet of basin 1 which is the central basin and which passes through the CRUTECH Staff Quarters, a combination of high commutative flow and very low gradient nearing zero, has led to such excessive flooding that a permanent swap plate has evolve in the area. Apart from directly inundating homes, such flood pools usually act as breeding ground for disease-carrying pathogens. Elsewhere, where channelization is done, blocking by refuse and other debris leads to a spillover from channel into streets and houses.

Within the study period, two of the types of floods identified by Adefolalu (2008) and Wolfgang (2012) were witnessed. The first was a flash flood condition that was usually associated with a $50 \mathrm{~mm}$ per 30 minutes rainfall. This was common during heavy thunderstorm which occurred mostly between the months of April - June and September - October, during late afternoons to night hours, although some mornings were also recorded.

A study of the rainfall and run-off responses also showed that after a heavy rainfall begins, several hours elapse before the basin mouths will begin to show a rise in discharge. This time lag indicates that the branching system of channels acts as a temporary reservoir, receiving inflow more rapidly than it could be passed down the channel system to the basin mouth. This observation conformed to what Granger (2010) described as channel storage during the early period of a storm.

\section{IMPLICATIONS FOR PLANNING}

For the central zone, stretching down south to the great Qua River, the Drainage Basin ap- 
proach is proposed. It is thus recommended that for effective remediation of flood problems in Calabar, a system of six major drainage channels be designed and constructed for the entire Calabar area, each receiving run-off from its tributaries and from its basin area. All the drainage basins identified as Basin 2, 3, 4, 5 and 6, which at present pour storm water into the central channel in basin 1 should each have their own major channels. Already as a response to a similar proposal by (Ugbong and Chima, 2009a), channel 2 has been developed using underground design as obtainable in Krasnodar, Russia (Figure 4). Unfortunately however, in this construction no provision is made for stormwater from residential neighbourhoods and road pavements to discharge into the underground channel. The error must be corrected when constructing the subsequent ones.

Since it has been shown there is a positive correlation between stormwater discharge on one hand, and gradient, surface area and length of a channel, there should also be an increasing down-stream expansion of each channel size to cope with increasing flow volume with distance from basin head to outlet. All channels should be aligned according to the natural course of flow of stormwater in each area. There should be less emphasis on open drains but more on closed ones and underground pipes with man-holes to take out surface water after every storm.

In the extremely low-lying territory of the south, where gradient is barely above the $10 \mathrm{~m}$ contour, and where stormwater hardly flows by gravity thereby resulting in massive flooding, this research proposes two approaches:

1) the "detaic design",

2) the Pumping method.

The 'deltaic design' is advocated for the southern extremity of Calabar where the central drainage channel takes all the stormwater and simply discharges it onto the floodplains of the adjoin Qua River, but which backs up and floods adjoining residential neighbourhoods. This will involve a system of river-delta-like channels, to distribute the stormwater into the Qua River at different segments (Figure 5). In the wider river basin system, the river breaks into a system of distributaries at the lower-most reach due to a combination of factors: loss of gradient which then impedes flow by gravity, excess sediment load brought from upstream. This forms the delta.

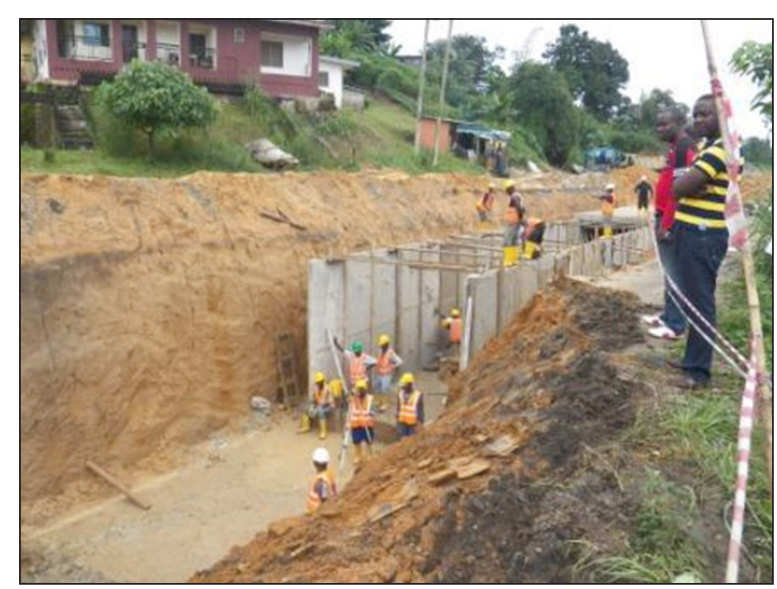

Figure 4. An underground canal under construction in Calabar (Photo by authors)

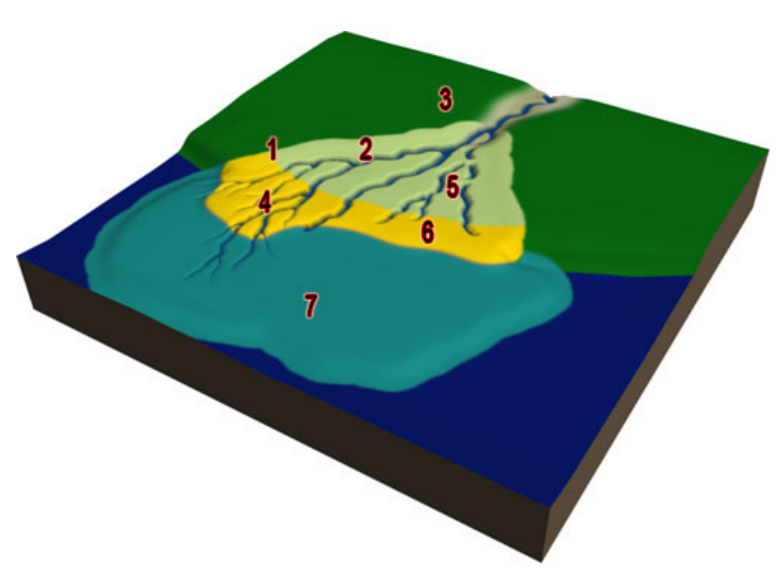

Figure 5. Sample model of a river basin Delta: 1 - limit of tidal inundation, 2 - upper deltaic plain, 3 - alluvial valley 4 . active delta, 5 - abandoned delta, 6 - lower deltaic plain, 7 - undersea deltaic plain [http://www.onegeology.org/extra/kids/earthprocesses/deltas.html]

\section{CONCLUSIONS}

In summary therefore, flooding in the Calabar region and particularly in areas of high population density, is caused by (1) high rainfall, (2) the type of slope or gradient of the given area, (3) impervious urban surfaces, (5) unplanned residential developments in the urban periphery, and 4) inadequate and improper drainage channels, due to non-alignment of existing drainage channels with the natural drainage characteristics of the specific areas, and the use of open drains instead of underground channels.

Solving this problem requires a lot of engineering work. For optimal result however, the following approaches are recommended: 
1. In addition to the engineering works being done, there should also be an ecological approach. This should be in the form of watershed protection and creation of green belts. In cities of Europe like Krasnodar, Russia, large acreages of city lands are carved out as parks. They are carefully forested and serve both as amenities and as protection against land degradation.

2. Waterlogged territories can be protected from other uses, and be used as protected wetlands for eco-tourism. This is called the "green infrastructure". But where absolutely necessary, waterlogged lands can be reclaimed using available technologies. This can be achieved by pumping out water and sand-filling.

3. Since engineering works are inevitable in built-up areas, special attention has to be paid to design details. Studies have shown the Calabar city region has a system of six drainage basins (Chima and Ugbong, 2009b). Each of these was supposed to have its own major channel to convey surface runoff away from the land. But this is not so: almost all runoff is diverted into the one central channel. Since the channel capacity is overstretched, it often overflows and causes flooding. Therefore, a system of six drainage channels should be designed and constructed. Already one of such is under construction in addition to the existing one. All details must be based on terrain as shown in attached figure.

4. Also, in an environment where there is a culture of dumping household waste into drainage channels, the use of open drains is not advisable. In cities like Krasnodar, Russia, a system of underground channels is used to convey both surface runoff and sewage water away from the land to adjoining rivers.

The implementation of the whole system of flood control in the Calabar region is very urgent and should be realized in one single step based on a master-plan. The scheme can be achieved by: (1) building flood retaining embankments or levees, (2) storage of flood water, (3) diversion of flood water, (4) improving discharge capacity of the river, (5) construction of spur dykes, and (6) by protecting watersheds and creating green belts. Selection of any one method or a combination of methods depends upon the purpose for which flood control is necessitated and the degree of control required. The cost should be minimized for economically viable solution to the problem.
Finally, in order to obtain a scientific database on flood problems in the region, it is suggested that a complete hydro-geomorphological research be done in the area. This is with a view to producing a simulation model of the Calabar drainage basin and its processes. By so doing, it will become easier to predict with reasonable accuracy the likelihood of flood occurrence and determine remedial measures.

\section{REFERENCES}

1. Chima G.N. and Innocent A. Ugbong 2009. Anomalous Bifurcation Ratios and Drainage Density Indexes as Indicators of Flood Conditions in Calabar Metropolis, Nigeria" in African Journal of Science and Engineering, 10(1), 2313-2326.

2. Chima, G.N. and I.A. Ugbong. 2009. Characterizing Surface Runoff and Urban Floods in the calabar Drainage Area. Journal of Science, Engineering and Technology, 16(2), 8829-8840.

3. Chocat, B., Ashley, R., Marsalek, J., Matos, M. R., Rauch, W., Schilling, W. and Urbonas, B. 2004. Position Paper. Urban Drainage - Out-of-sight-outof-mind? IAHR/IWA Joint Committee on Urban Drainage. Novatech 2014, GRAIE, 1659-1690.

4. Chocat, B., Ashley, R., Marsalek, J., Matos, M. R., Rauch, W., Schilling, W. and Urbonas, B. 2007. Towards the Sustainable Management of Urban Storm-water. Indoor and Built Environment 2007, 17, 273-285.

5. Cunningham, W.P., Cunningham, M.A. and Saigo, B.W. 2007. Environmental Science, A Global Concern." Ninth edition. The McGraw Hill Companies. Inc. New York, USA.

6. Granger, D., Cherqui, F. and Chocat, B. 2010. EAR methodology: an approach to Sustainable Urban Water Management. IWA (Int. Water Assoc.) World Water Congress and Exhibition, Sep 2010, Montreal, Canada, pp. 1-4.

7. Itam, E.B.; Ukorebi, U.A.; Ita, E.E.; Ugbong, I. A.; Obia, A.E.; Yaro, M.A.; Ekeng, P.O. 2015. Ikot Uduak Episode: Storm Water Management as a Challenge in Sustainable Development of Urban Residential Communities in Calabar. The International Journal of Science and Technoledge, 3(6). 290-302.

8. Itam E.B., Ukorebi U.A., Yaro M.A., Ita E.E., Ugbong I.A., Ipia O.B., Ekeng P.O. 2015. Tracing Ecological Disasters through Poor Planning of Infrastructure for Housing Development: The Ikot Nkebre Episode in Calabar, Nigeria. The International Journal of Science and Technoledge, 3(8), 89-101.

9. Strahler, A.H and Strahler, A.N. 1979. Environmental Geo-science: Interaction between Natural Systems and Man. J.N. and Sons Ltd., N.Y., USA. 
10. Tesco-Kozti, 2011. Calabar Survey and Development Plan. Kozti, Budapest.

11. Ugbong, I.A. and I.V. Budagov. 2016. Formulating an Optimal Drainage Model for the Calabar Area Using Cartographic Techniques, Journal of Ecological Engineeering, 17(1), 1-9.

12. Parkinson, J. 2010. Drainage and stormwater management strategies for low-income urban communities. Environment and Urbanization, 15(2), 115-120.

13. Wolfgang R., R. Seggelke, R. Brown, P. Krebs. 2012. Integrated Approaches in Storm Drainage: Where do We Stand? Environmental Management, 35(4), 396-409,
14. Parker, E.A. 2015. Models in flood plain management. Journal of Hydrology, 41(1).

15.Zhou, Q. 2014. A Review of Sustainable Urban Drainage Systems Considering the Climate Change and Urbanization Impacts. Water, 6(4), 976-992.

16. Zieder, A.D., Tran, T.L. and Giambelluca, I. W. 2006. Effective slope lengths for buffering hillslope surface run-off in fragmented landscapes in North Vietnam. Journal of Soil and Water Conservation, July 30.

17. http://www.onegeology.org/extra/kids/earthprocesses/deltas.html 